\title{
1,6-DIHYDRO-NAD AS AN HUMIDITY-INDUCED LACTATE DEHYDROGENASE INHIBITOR IN NADH PREPARATIONS
}

\author{
by
}

SVEN ERIK GODTFREDSEN and MARTIN OTTESEN

\author{
Department of Chemistry, Carisberg Laboratory, \\ Gamle Carlsberg Vej 10, DK-2500 Copenhagen, Valby
}

Keywords: 1,6-dihydro-NAD, lactate dehydrogenase inhibitor, NADH, DEAE-chromatography, NAD oxidoreductase, high performance liquid chromatography

\begin{abstract}
An authentic mixture of 1,2-, 1,4- and 1,6-dihydro-NAD was characterized by high pressure liquid chromatography. Pure 1,6-dihydro-NAD isolated from this mixture was shown to be a potent inhibitor of lactate dehydrogenase and to exhibit an UV spectrum identical to that of an extensively purified lactate dehydrogenase inhibitor generated by exposing NADH to moisture. The humidity induced inhibitor, which could not be separated from NADH by DEAE chromatography, cochromatographed with 1,6-dihydro-NAD during both DEAE and high pressure liquid chromatography and is therefore presumably identical to 1,6-dihydro-NAD.
\end{abstract}

\section{INTRODUCTION}

The widespread use of NADH to determine absolute enzyme reaction rates is hampered by the generation of enzyme inhibitors which takes place in NADH preparations even under very mild conditions. For example, potent enzyme inhibitors, some of known and others of unknown constitution, are formed simply when $\mathrm{NADH}$ is exposed to moisture or, as another example, when an aqueous solution of the nucleotide is lyophilized $(2,6)$. This situation has prompted the development of methods for removing enzyme inhibitors from and methods for determining the purity of NADH preparations. As a result, chromatography on DEAE cellulose has become a widely accepted method for purifying NADH $(4,6)$ and the ratio between the extinction coefficients at $260 \mathrm{~nm}$ and 340 $\mathrm{nm}$ has become a preferred measure of the purity of NADH samples since, until recently, 
no inhibitor detected in NADH preparations exhibited an absorption at $340 \mathrm{~nm}$ (5). Recently, however, it was observed that exposure of NADH to moisture results in formation of a potent, but hitherto unnoticed enzyme inhibitor which exhibits an absorption at $340 \mathrm{~nm}(3,5)$, and cochromatographs with $\mathrm{NADH}$ during DEAE chromatography (5). The mode of formation and the observed behaviour of this new inhibitor points towards an NADH isomer. As described in the present communication this possibility has ben checked by analysing an authentic mixture of the three isomeric forms of NADH (1,2-, 1,4- and 1,6-dihydro-NAD) and by demonstrating that one of these compounds (1,6-dihydro-NAD) is identical to the new, humidity induced inhibitor.

\section{MATERIALS AND METHODS}

$\mathrm{NAD}^{+}$and NADH were commercial preparations manufactured from brewers yeast by the Carlsberg Breweries, Denmark. Lactate dehydrogenase (LDH) was a gift from Dr. S. BAYNE and prepared from pig hearts. Alcohol dehydrogenase was purchased from Boehringer Co., Germany as a lyophilized powder. DEAE cellulose was from Whatman, England. Tris (hydroxymethyl) methylamine (TRIS) was from Sigma Company, U.S.A. Sodium borohydride was from Merck Company, Germany, and ammonium bicarbonate was a product from Bakers' Chemicals.

High pressure liquid chromatography (HPLC) was carried out with a Hewlett Packard 1084 instrument equipped with a fixed wavelength UV detector Model $1036 \mathrm{~A}$ and a $\mu$ Bondapak $\mathrm{C}_{18}$ column purchased from Waters Associates. The elution solvent was $0.02 \mathrm{M}$ phosphate buffer, $\mathrm{pH} 7$, and the flow rate $2 \mathrm{ml} /$ $\min$ at $40^{\circ}$.

LDH reaction rates with pyruvate as substrate were determined as described by GerhardT et al. (2).

An authentic mixture of 1,2-, 1,4- and 1,6dihydro-NAD was prepared by a modification of the published procedure (1). $\mathrm{NAD}^{+}(50 \mathrm{mg})$ was dissolved in TRIS buffer $(5 \mathrm{ml}, 0.1 \mathrm{~m}, \mathrm{pH}$ $8.5)$ and solid sodium borohydride $(5 \mathrm{mg}$ ) was added to the stirred solution at room temperature. The reduction was allowed to proceed for 10 minutes whereupon the bright yellow reaction mixture was applied directly to a column of DEAE cellulose and eluted with a linear gradient of ammonium bicarbonate.

\section{RESULTS AND DISCUSSION}

Humidity induced inhibitors were generated essentially as described elsewhere $(2,5)$ by adding water to solid NADH in a ratio of $1: 1$ by weight. After 24 hours at room temperature the mixture was chromatographed on DEAE cellulose $(4,6)$ and fractions containing NADH analysed by high pressure liquid chromatography. In accordance with previous findings (5) a minor peak appeared before the major peak

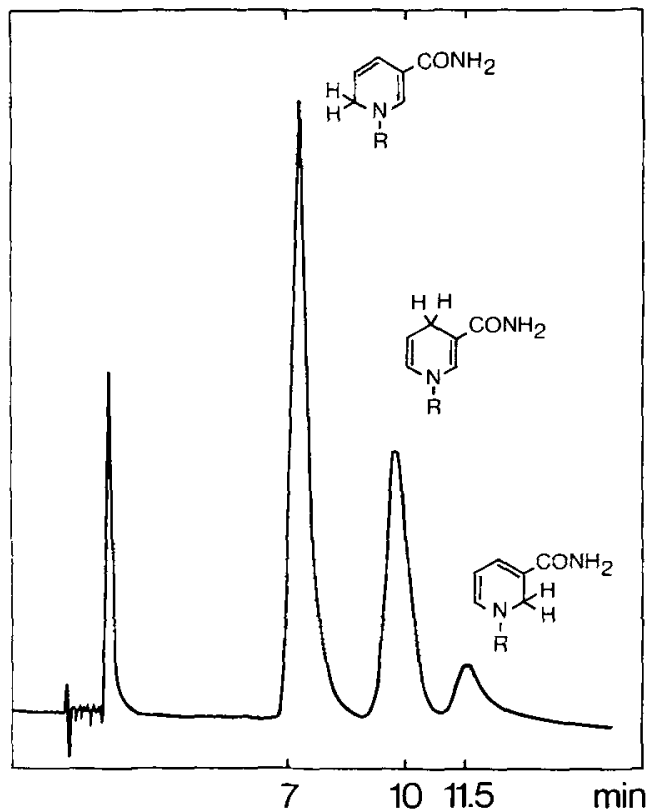

Figure 1. HPLC chromatogram of an authentic mixture of 1,2-, 1,4- and 1,6-dihydro-NAD prepared as described in Section 2 . The column was a $\mu$ Bondopak $\mathrm{C}_{18}$ and the elution solvent $0.02 \mathrm{M}$ phosphate buffer, $\mathrm{pH} 7$.

Abbreviations: $\mathrm{LDH}=$ lactate dehydrogenase; $\mathrm{NAD}^{+}=$nicotinamide adenine dinucleotide; $\mathrm{NADH}=1,4-$ dihydro-nicotinamide adenine dinucleotide. 


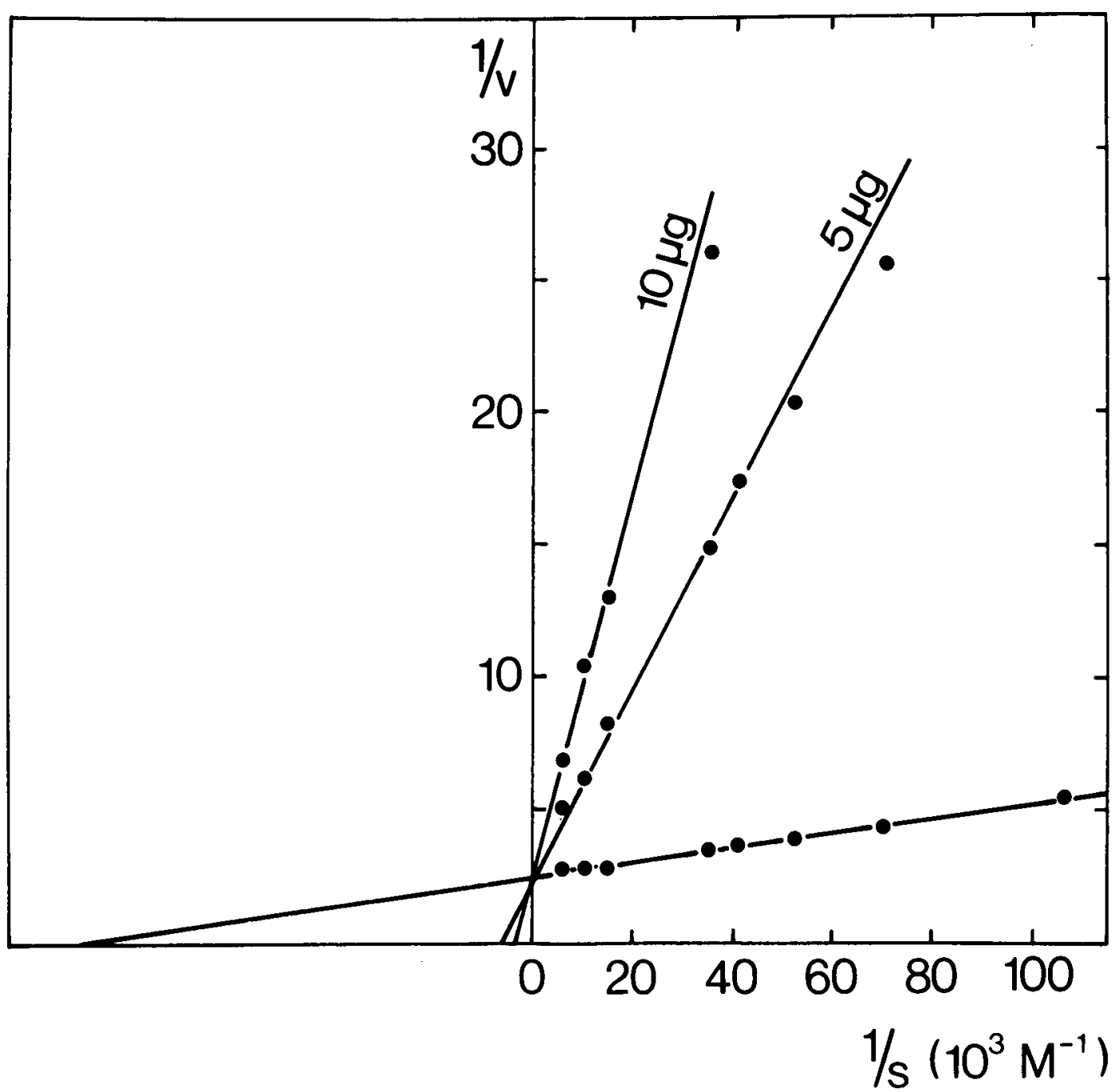

Figure 2. Double-reciprocal plots of relative reaction rates with pyruvate and LDH as function of NADH concentration with 0,5 and $10 \mu \mathrm{g}$ 1,6-dihydro-NAD added per ml reaction mixture. Experimental conditions are specified by Gerhardt et al. (2). From the slopes $K_{i}$ was calculated to $0.6 \cdot 10^{-6}$ molar.

corresponding to NADH (retention time 7.0 min and $10.0 \mathrm{~min}$, respectively). Under similar conditions an authentic mixture of 1,2-, 1,4- and 1,6-dihydro-NAD, prepared as described in Section 2, gave rise to a chromatogram with peaks at $7.0 \mathrm{~min}, 10.0 \mathrm{~min}$ and $11.5 \mathrm{~min}$ (Fig. 1). The compound corresponding to the $10 \mathrm{~min}$ peak was easily identified as NADH by comparison with an authentic sample. The latest appearing compound was unstable and this indicates that the 11.5 min peak corresponds to 1,2-dihydro-NAD (1). The compound which appeared after $7 \mathrm{~min}$ and which cochromatographed with the humidity induced inhibitor could thus be tentatively identified as 1,6-dyhydro-NAD.

Pure 1,6-dihydro-NAD was made available by a modification of the procedure described in the literature (1) in order to determine its properties as an LDH inhibitor and its UV characteristics. NAD ${ }^{+}(100 \mathrm{mg})$ was dissolved in TRIS buffer ( $5 \mathrm{ml}, 0.1 \mathrm{M}, \mathrm{pH} 8.5$ ) and portions $(5 \mathrm{mg})$ of solid sodium borohydride were added to the resulting solution at 10 
minutes intervals during 50 minutes. The reaction mixture was left for $30 \mathrm{~min}$ at room temperature and then chromatographed on DEAE cellulose as described above. Fractions containing NADH were pooled and shown by HPLC analysis to contain two components with retention time $7 \mathrm{~min}$ and $10 \mathrm{~min}$, respectively. Carbon dioxide was bubbled into the pooled fractions in order to adjust $\mathrm{pH}$ of the solution to 7. NADH was then converted into $\mathrm{NAD}^{+}$by incubating the mixture for $15 \mathrm{~min}$ at room temperature with alcohol dehydrogenase $(2 \mathrm{mg})$ and subsequently added acetaldehyde $(0.15 \mathrm{ml})$. The enzyme was removed by filtration through an Amicon PM 10 membrane and the filtrate shown by HPLC analysis to contain two components with retention time $7 \mathrm{~min}$ and 7.5 min, corresponding to 1,6-dihydro-NAD and $\mathrm{NAD}^{+}$, respectively. The filtrate was freeze dried and the remanence chromatographed on DEAE cellulose, where $\mathrm{NAD}^{+}$is eluted well separated from NADH and its isomers. Fractions absorbing at $340 \mathrm{~nm}$ were pooled, shown by HPLC analysis to contain a single component with retention time $7 \mathrm{~min}$, and finally freeze dried to provide pure 1,6-dihydro-NAD.

The properties of 1,6-dihydro-NAD as an LDH inhibitor were investigated as described by GERHARDT et al. (2). The results shown in Fig. 2, indicate that 1,6-dihydro-NAD is a potent competitive inhibitor of lactate dehydrogenase with a $\mathrm{K}_{\mathrm{i}}$ of approximately $0.6 \mu$ molar. Like the recently detected humidity induced inhibitor, 1,6-dihydro-NAD proved unstable

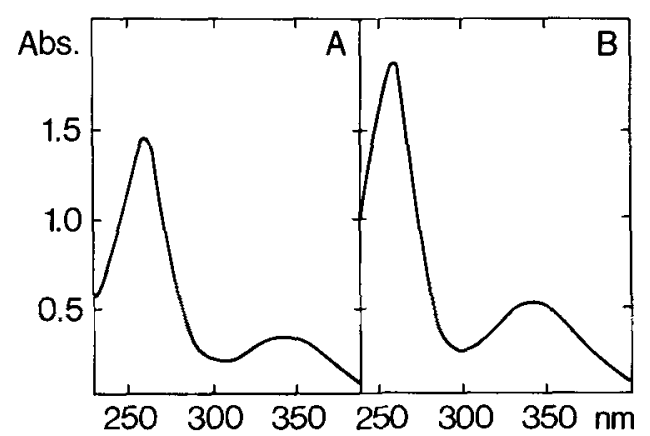

Figure 3: A: UV spectrum of 1,6-dihydro-NAD, 0.05 mg per ml 0.02 molar phosphate buffer, $\mathrm{pH} 7$. B: UV spectrum of the inhibitor isolated from a humid NADH preparation as specified in Section 3. in phosphate buffer at $\mathrm{pH} 7$, with a half life of approximately two days.

The UV spectrum of 1,6-dihydro-NAD exhibits maxima at $259 \mathrm{~nm}$ and $345 \mathrm{~nm}$ with a ratio between the extinction coefficients at these wavelengths of 4.25 (Fig. $3 \mathrm{~A}$ ). This UV spectrum was compared with that of the humidity induced inhibitor prepared by converting the NADH in a sample of the inhibitor (cf. above) into $\mathrm{NAD}^{+}$with the aid of alcohol dehydrogenase and by separating the oxidized nucleotide from the inhibitor by chromatography on DEAE cellulose (cf. preparation of 1,6dihydro-NAD). The resulting UV spectrum of the humidity induced inhibitor exhibits maxima at $259 \mathrm{~nm}$ and $344 \mathrm{~nm}$, the ratio between the extinction coefficients at these wavelengths being 4.21 (Fig. 3B).

Since 1,6-dihydro-NAD is a potent inhibitor of lactate dehydrogenase, since it cochromatographs with the humidity induced inhibitor during both DEAE- and high pressure liquid chromatography, and since it exhibits an UV spectrum identical to that of the inhibitor it seems likely that the recently detected humidity induced inhibitor $(3,5)$ is identical with 1,6 dihydro-NAD. It is conceivable that this compound is generated in NADH samples by a two step process which, as its first step, involves oxidation of small amounts of NADH to $\mathrm{NAD}^{+}$and, as the second step, conversion of this material into 1,6-dihydro-NAD by transfer of hydride from NADH. By this mechanism $\mathrm{NAD}^{+}$might catalyze the isomerisation of $\mathrm{NADH}$ to 1,2- and 1,6-dihydro-NAD.

\section{ACKNOWLEDGEMENTS}

The authors are most grateful to Mrs. HANNE CHRIstiansen for her skilled technical assistance and to Mr. LINDY SøNDERGAARD for drawing the figures.

\section{REFERENCES}

1. Chaykin, S., L. KIng \& J. G. Watson: The reduction of $\mathrm{DPN}^{+}$and $\mathrm{TPN}^{+}$with sodium borohydride. Biochim. Biophys. Acta. 124, 13-23 (1966)

2. Gerhardt, W., B. Kofoed, L. Westlund \& B. 
PAVLU: Quality control of NADH, Supplement 139, J. Clin. Lab. Invest., Stockholm (1974)

3. Loshon, C. A., R. B. McComB, L. W. Bond, G. N. BOWERS Jr., \& R. H. GWYNN: Formation and properties of lactate dehydrogenase inhibitors in NADH. Clin. Chem. 23, 1576-1580 (1977)

4. Margolis, S. A., B. F. Howell \& R. SchafFer: Purification and analysis of the purity of NADH. Clin. Chem 22, 1322-1329 (1976)
5. Margolis, S. A., B. F. Howell \& R. Schaffer: Lactate dehydrogenase inhibitors in NADH preparations. Clin. Chem. 23, 1581-1584 (1977)

6. Strandjord, P. E. \& K. J. Clayson: The control of inhibitory impurities in reduced nicotinamide adenine dinucleotide in lactate dehydrogenase assay. J. Lab. Clin. Chem. 67, 144-153(1966) 